\title{
ЗАПИТ НА ДОСТУП ДО ПУБЛІЧНОЇ ННФОРМАЦІЇ: СПЕЦИФІКА ВІДЕО-, АУДІОМАТЕРІАЛІВ 3 УРАХУВАННЯМ ОХОРОНИ ПРАВА НА ПРИВАТНІСТЬ
}

\author{
ІВАНОВ Денис Валерійович - кандидат юридичних наук, інформаційний \\ аналітик-міжнародник, доцент кафедри міжнародних відносин Українсько- \\ Польського ВНЗ «Центрально-Свропейський університет»
}

DOI:10.32782/NP.2019.4.8

УДК 342.9:342.7:347

В статъе рассматриваются дискуссионнъие положения Закона Украинъ «О доступе $\kappa$ публичной инбормации» о возможностях квалификации видео и аудиоматериалов, как публичной инбормачии, учитьивая критерии «отображенности» $u$ «задокументированности», анализируются ограничения реализаизи права на доступ к таким материалам посредством распространения их через дополнительные сервисъ, такие как: WeTransfer, YouTube, Google Disk или записи на оптические носители; описъваются проблемъ соотношения доступа к конфиденицальной информации и зашить права на приватность запрашиваюшего и третьих лии; отмечается дискуссионность материальньх и технических возможностей реализации положений части седьмой статьи 6 Закона (о предоставлении доступа к документу, в котором содержится инббормачия с ограниченным доступом) в случае применения этого положения $к$ видео и аудиоматериалам; представленъ направления совершенствования законодательства для решения описаннъгх проблем.

Ключевъе слова: запрос на публичную инбормацию, видео и аудиоматериаль, отображенность, задокументированность, приватность.

Постановка проблеми

Закон України «Про доступ до публічної інформації» (далі - Закон) був прийнятий у 2011 році [1]. Тоді було чимало питань про те як буде функціонувати такий прогресивний акт в українському суспільстві. По- ложення Закону у момент прийняття - це здебільшого дослівна копія Закону «Про доступ до публічної інформації» однієї з сусідніх держав, 3 тим тільки застереженням, що в українській версії автори Закону позбулися певних спеціальних норм оригінальної версії. Незважаючи на це, базові положення та механізми Закону залишилися без змін, а у подальшому до Закону вже вносилися поправки з огляду на прогресивні ідеї локальних еліт або ж у зв'язку з необхідністю вирішення тих чи інших прикладних завдань. 3'явилася судова практика та наукові роботи, які сприяють розумінню положень Закону, але деякі питання і надалі залишають за полем уваги. Одним 3 таких мало опрацьованих аспектів є доступ до відео- та аудіоматеріалів, зокрема надання таких матеріалів на інформаційний запит.

\section{Аналіз}

Питаннями доступу до публічної інформації, надання іiі на інформаційний запит займалися Н.Каменська [2], А. Благодарний [3], О. Нестеренко, Т. Шевченко та чимало інших дослідників. Водночас опрацювань, у яких би аналізувався доступ до відео та аудіоматеріалів, зокрема надання таких матеріалів на інформаційний запит, знайти не вдалося.

\section{Формулювання цілей}

3 огляду на неопрацьованість питань доступу до відео- та аудіоматеріалів на інформаційний запит у цій статті здійснено аналіз можливості надання такої інформації. 


\section{Виклад основного матеріалу}

У Науково-практичному коментарі до Закону України "Про доступ до публічної інформації” зазначається, що публічна інформація може мати текстове, числове, графічне вираження чи бути виражена вербальними засобами тощо. Як приклад автори наводять цифрове зображення, що міститься на жорсткому диску комп'ютера, фотоапараті чи в мобільному телефоні) $[4,43]$. Натомість як бути з громіздкими відео та аудіоматеріалами? Чи $\epsilon$ вони публічною інформацією відповідно до Закону та чи можуть вони надаватися на інформаційний запит?

Можливість позитивно відповісти про те, що відео- та аудіоматеріали належать до публічної інформації обумовлена застереженням, адже відео та аудіо матеріали мають відповідати критеріям, які встановив законодавець, а саме «публічна інформація - це відображена та задокументована... інформація[1]».

Критерій «відображена» є дискусійним не тільки сам по собі, але також і по відношенню до цифрових матеріалів. Що можна розуміти під терміном «відображена»? Слово «відображена» походить від «образ», тобто щось, що можна споглядати в уяві чи в реальності. Таким чином, будь-яка доступна для візуального сприйняття інформація $є$ відображеною. У випадку цифрових матеріалів можна говорити про те, що відображеною є інформація про такі матеріали, яку можна споглядати на екрані монітора - тобто назва файлу, дата його створення тощо. Проте реквізити - це не документ, а тому у деяких випадках про відображеність інформації говорити не слід. Так, у випадку аудіофайлів критерій «відображеності» інформації $є$ найбільш дискусійним - ми не можемо споглядати звук, те саме стосується і відео зі звуком. Варто також зазначити, що у випадку відео теж можуть бути аргументи «проти», адже «образ» архаїчно сприймається як щось статичне. Звісно, можна спекулювати, наводячи приклад рухомих образів. Таким чином, якщо розуміти термін «відображена» так, як було описано вище, то задоволення критерію «відображеності» відео- та аудіоінформації є частковим. 3 огляду на зазначену дискусійність термін «відображена» було 6 доцільно замінити на термін «зафіксована» або взагалі вилучити з Закону.

Другий критерій - «задокументованість» інформації. Застосовування цього критерію до інформації обумовлено нинішнім підходом законодавця до дефініції поняття документ. Відповідно до Закону України «Про інформацію» документ - матеріальний носій, що містить інформацію, основними функціями якого є ії збереження та передавання у часі та просторі [5]. Альтернативне визначення поняття «документ» знаходимо у Законі України «Про обов'язковий примірник документів» [6] та Законі України «Про бібліотеки і бібліотечну справу» [7], у яких надається така дефініція: «документ матеріальна форма одержання, зберігання, використання і поширення інформації, зафіксованої на папері, магнітній, кіно-, фотоплівці, оптичному диску або іншому носієві [6; 7]». Запропоновані дефініції ототожнюють документ з будь-яким матеріальним носієм інформації незалежно від формальних критеріїв, наприклад, напис на паркані чи на камені теж може розглядатися як документ.

3 огляду на такий підхід законодавця відео- та аудіоматеріли можна вважати задокументованою інформацією. Документом у такому випадку є жорсткий диск комп'ютера, CD, DVD, оптичний носій інформації тощо. Як у такому випадку може бути наданий доступ до таких матеріалів у відповідь на інформаційний запит? Чи законодавець дійсно був такий прогресивний у свої поглядах на те чим $є$ документ?

Аналіз Закону дозволяє стверджувати про відсутність прогресивного підходу, якщо мова йде про громіздкі відео та аудіоматеріали. Пояснюється це тим, що законодавцем передбачено відшкодування витрат за виготовлення копій документів обсягом більш як 10 сторінок (ст. 21 Закону), але не передбачено відшкодування витрат за оптичні носії інформації, на які можна було 6 здійснити запис інформації. Також Законом не передбачено можливість отримати відповідь на запит у вигляді інформації на оптичному носії.

Відео- та аудіофайли можуть бути надіслані електронною поштою, якщо особа 
вказала у запиті такий спосіб отримання інформації. Натомість у випадку громіздких даних надіслати їх безпосередньо, без додаткових сервісів, таких як WeTransfer, YouTube aбо Google Disk, може бути неможливо. Водночас, використовуючи сервіси поширення/зберігання даних, суб'єкт владних повноважень вступає у договірні відносини 3 посередниками, предметом яких є аудіоабо візуальні матеріали, які можуть стосуватися особистих немайнових прав третіх осіб або й самого запитувача інформації. Такі дії суб'єкта владних повноважень (без згоди осіб, чиїх немайнових прав стосується відео або аудіоматеріал) є порушенням права на приватність, злочином, санкція за який передбачена статтею 182 Кримінального Кодексу України [8].

Ще одне застереження, яке стосується доступу до конфіденційної інформації, пов'язане 3 феноменом анонімності. У випадку інформаційного запиту суб'єкт владних повноважень не має обов'язку перевірки інформації про особу запитувача. Відтак, послуговуючись чужим ПІБ, запитувач, формально виконавши вимоги, передбачені статтею 19 Закону, повинен отримати від суб'єкта владних повноважень інформацію. У випадку відкритих даних висвітлений аспект витримує критику. Натомість недоопрацюванням слід вважати те, що, послуговуючись чужим ПІБ, запитувач може отримати також інформацію 3 обмеженим доступом. Статтею 10 Закону передбачено спеціальні норми, якими гарантується право кожного на доступ до інформації про себе, натомість не передбачено жодних спеціальних процедур, пов'язаних з перевіркою особи запитувача, відтак наявне поле для зловживань.

Слід зауважити, що у Законі закладено презумпцію «порядного запитувача», натомість не передбачено превентивних механізмів захисту конфіденційної інформації необмеженого кола осіб у випадку зловживань. Крім того, суб'єкт владних повноважень не в праві вимагати від запитувача додаткових відомостей, що підтвердили б його особу, оскільки Законом передбачено вичерпний перелік вимог до запиту. Таким чином, суб'єкт владних повноважень має два сценарії, які може застосовувати при розгляді запитів на публічну, конфіденційну інформацію: 1) використовувати презумпцію «порядного запитувача» як пріоритетну - надаючи інформацію про особу, що виконала формальні критерії Закону;2) використовувати як пріоритет захист права на приватність, обмежуючи доступ до інформації на підставі положення частини другої статті 6 Закону з метою «запобігання розголошення інформації, одержаної конфіденційно[1]» .

Прикладний аспект проблем застосування Закону щодо описаного вище доповнює положення пункту 3 частини третьої статті 10 Закону, відповідно до якого: «Розпорядники інформації, які володіють інформацією про особу, зобов'язані: 3) вживати заходів щодо унеможливлення несанкціонованого доступу до неї інших осіб [1]».

Зазначене вище дозволяє стверджувати про необхідність доопрацювання окремих положень Закону, зокрема створення механізмів для можливості перевірки особи запитувача суб'єктами владних повноважень у випадках доступу до конфіденційної, у тому числі «чутливої» інформації.

Ще одним дискусійним аспектом у випадку доступу до відео- та аудіоматеріалів є практична реалізація частини сьомої статті 6 Закону, відповідно до якої «обмеженню доступу підлягає інформація, а не документ. Якщо документ містить інформацію з обмеженим доступом, для ознайомлення надається інформація, доступ до якої необмежений [1]».

У випадку, якщо на відео або аудіоматеріалах наявні треті особи, реалізація процитованого положення означала 6 необхідність монтажу матеріалів таким чином, аби персональні данні третіх осіб були вилучені - мають бути вилучені голоси третіх осіб, вилучені елементи відео, на яких видно, як виглядають треті особи тощо. Виникає питання про матеріальне забезпечення суб'єктів владних повноважень для реалізації зазначено та про рівень професійної підготовки осіб, що мають здійснювати такі дії, адже для виконання таких маніпуляцій з аудіо- та відеоматеріалами, має застосуватися відповідне програмне забезпечення підготовленим до такої роботи виконавцем. 


\section{АНОТАЦІЯ}

у статті розглядаються дискусійні положення Закону Украӥни «Про доступ до публічної інформачї̈» щодо можливостей кваліфікачї відео- та аудіоматеріалів, як публічної інформачїі, з огляду на критерї̈ «відображеності» та «задокументованості», аналізуються обмеження реалізачіӥ права на доступ до таких матеріалів за допомогою поширення їх через додаткові сервіси, такі як: WeTransfer, YouTube, Google Disk або запису на оптичні носї; описуються проблеми співвідношення доступу до конфбіениійної інбормачї̈ та захисту права на приватність запитувача та третіх осіб; зазначається про дискусійність матеріальних та технічних можливостей реалізачії положень частини съомої статті 6 згаданого Закону (щодо надання доступу до документу, у якому міститься інформація з обмеженим доступом) у випадку застосування цъвого положення до відео та аудіоматеріалів; представлено напрямки удосконалення законодавства для вирішення висвітлених проблем.

Ключові слова: запит на публічну інформаиію, відео та аудіоматеріали, відображеність, задокументованість, приватність.

\section{Висновки}

У Законі наявні недоопрацювання, які потребують подальшої парламентарної роботи для їх усунення.

\section{Література}

1. Закон України «Про доступ до публічної інформації» [Електронний ресурс] - Режим доступу до ресурсу: https://zakon. rada.gov.ua/laws/show/v0010760-16. - Назва 3 екрану. - Дата доступу: 10.11.2019.

2. Каменська Н.П. Реалізація права на доступ до публічної інформації за інформаційними запитами / Н.П. Каменська. // Інформація і право. - 2011. - № 3(3). - С. 64-69.

3. Благодарний А. М. Адміністративна відповідальність за відмову в наданні інформації посадовим особам правоохоронних органів / Андрій Миколайович Благодарний. // Інформаційна безпека людини, суспільства, держави. - 2013. - №2(12). - С. 92-96.

\section{SUMMARY}

In this article we discuss the provisions of the Law of Ukraine "On Access to Public Information" regarding the possibilities to qualify video and audio materials as public information, using such criteria as: "displayed" and "documented". Also, we analyze the restrictions on the exercise of the right to access such materials through their dissemination using additional services such as WeTransfer, YouTube, Google Disk, or optical media recording. We describe the issues relating to the relationship between access to confidential information and the protection of the right of privacy of the requester and third parties. We mention our doubts on material and technical possibilities of implementing the provisions of article 7, paragraph 6 of the Law (regarding access to a document containing restricted information) in the case of application of this provision to video and audio materials. We offer directions for improving legislation to solve identified problems.

Keywords: request for public information, video and audio materials, displayed, documented, privacy.

4. Науково-практичний коментар до Закону України «Про доступ до публічної інформації» / Р. Головенко, Д. Котляр,О. Нестеренко, Т. Шевченко. - Київ, 2012. 335 с. - (СПД Гончарук А.Б.).

5. Закон України «Про інформацію» [Електронний ресурс] - Режим доступу до pecypcy: https://zakon.rada.gov.ua/laws/ show/2657-12. - Назва з екрану. - Дата доступу: 22.12.2019.

6. Закон України «Про обов'язковий примірник документів» [Електронний ресурс] Режим доступу до ресурсу: https://zakon.rada. gov.ua/laws/show/595-14/ed20160113\#n12. Назва з екрану. - Дата доступу: 20.11.2019.

7. Закон України «Про бібліотеки і бібліотечну справу» [Електронний ресурс] - Peжим доступу до ресурсу: https://zakon.rada. gov.ua/laws/show/32/95-\%D0\%B2\%D1\%80/ ed20170101. - Назва з екрану. - Дата доступу: 20.11.2019.

8. Кримінальний кодекс України [Електронний ресурс] - Режим доступу до ресурcy: https://zakon.rada.gov.ua/laws/show/234114\#n1190. - Назва з екрану. - Дата доступу: 23.11.2019. 